\title{
Influence of Temperature on Mycelial Growth of some Pleurotus eryngii and Lentinula edodes Strains in vitro
}

\author{
Valentin ZĂGREAN ${ }^{*}$, Gabriela NEAŢĂ², Bogdan STĂNCIULESCU ${ }^{1}$ \\ ${ }^{1}$ Research Institute for Vegetable and Flower Growing Vidra, Romania \\ ${ }^{2}$ University of Agronomic Sciences and Veterinary Medicine - Faculty of Agriculture, Bucharest, \\ Romania \\ *)Corresponding author, e-mail: valentinzagrean@yahoo.com
}

BulletinUASVM Horticulture 74(1) / 2017

Print ISSN 1843-5254, Electronic ISSN 1843-5394

DOI:10.15835/buasvmcn-hort:12353

\begin{abstract}
The mycelial growth rate of eight experimental strains - Pleurotus eryngii (4) and Lentinula edodes (4) - was studied on PDA medium at different incubation temperatures: $18^{\circ} \mathrm{C}, 24^{\circ} \mathrm{C}$ and $30^{\circ} \mathrm{C}$. The aim of the investigation was to determine the optimal temperature for in vitro cultivation of each of the eight strains under study. All the experimental soushes reached their optimum growth at $24-30^{\circ} \mathrm{C}$. P. eryngii strains showed better growth rates compared to those of L. edodes. The fastest strains were Pery- $\mathrm{G}\left(4,83 \mathrm{~mm}^{-1 a y^{-1}} / 30^{\circ} \mathrm{C}\right)$, Pery-K $\left(4,14 \mathrm{~mm}^{-1 a y^{-1}} / 30^{\circ} \mathrm{C}\right)$

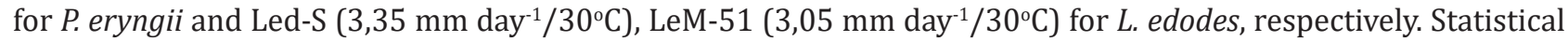
analyses show that experimental strains of both species obtained very significant positive results at $30^{\circ} \mathrm{C}$.
\end{abstract}

Keywords: Lentinula edodes, mycelium, Pleurotus eryngii

\section{Introduction}

Pleurotus eryngii (King oyster) and Lentinula edodes (shiitake) are two of the most important and popular cultivated mushrooms worldwide. These speciality mushrooms are considered as a delicacy with high nutritional and functional value and are also accepted as nutraceutical foods. They are of considerable interest because of their organoleptic merit, medicinal properties and economic significance (Chang and Miles, 2008; Chen et al., 2013). Successful cultivation of these mushrooms requires a spawn with high productive potential, able to quickly colonize the culture substrate. Factors such as composition and $\mathrm{pH}$ of the nutrient medium, temperature and $\mathrm{CO}_{2}$ concentration play an essential role in growth of the mycelium and preparing of the next mushrooms production. (Philippoussis, 2009). This paper examines the influence of temperature on mycelial growth of some P. eryngii and L. edodes strains of different origins.

\section{Aims and objectives}

The aim of the investigation was to determine the optimal temperature for in vitro cultivation of each of the eight studied strains.

\section{Materials and methods}

Eight different strains, P. eryngii - 4 and $L$. edodes -4 , were used in experiments. P. eryngii: Pery-G, Pery-R and Pery-26 were obtained from the Center of Applied Biochemistry and Biotechnology - BIOTEHNOL Bucharest and Pery-K from the Research Institute for Vegetable and Flower Growing - RIVFG Vidra. L. edodes strains Led-S, Led-C were obtained from BIOTEHNOL Bucharest and LeM-51, LeM-52 from RIVFG Vidra. The isolates were inoculated and grown on PDA media in tubes/Petri dishes. Mycelium extension rates were evaluated at $18^{\circ} \mathrm{C}, 24^{\circ} \mathrm{C}$ and $30^{\circ} \mathrm{C}$. The experiments were arranged in a randomized complete design with 
Tab. 1. Influence of temperature on mycelial growth of four P. eryngii strains

\begin{tabular}{ccccc}
\hline \multirow{2}{*}{ Temperature } & \multicolumn{4}{c}{ Mycelium growth rate $\left(\mathrm{mm}\right.$ day $\left.{ }^{-1}\right)-\mathrm{PDA}, \mathrm{pH}$ 6.5 - } \\
\cline { 2 - 5 } & Pery-G & Pery-K & Pery-R & Pery-26 \\
\hline $18^{\circ} \mathrm{C}$ & 2.15 & 1.85 & 1.30 & 1.73 \\
\hline $24^{\circ} \mathrm{C}$ & $3.35^{c}$ & $2.95^{c}$ & $1.75^{d}$ & $2.40^{d}$ \\
\hline $30^{\circ} \mathrm{C}$ & $4.83^{a}$ & $4.14^{a}$ & $3.53^{a}$ & $4.08^{a}$ \\
\hline
\end{tabular}

Tab. 2. Influence of temperature on mycelial growth of four L. edodes strains

\begin{tabular}{ccccc}
\hline \multirow{2}{*}{ Temperature } & \multicolumn{4}{c}{ Mycelium growth rate $\left(\mathrm{mm}\right.$ day ${ }^{-1}$ - PDA, $\mathrm{pH}$ 6.0 - } \\
\cline { 2 - 5 } & LeM-51 & LeM-52 & Led-S & Led-C \\
\hline $18^{\circ} \mathrm{C}$ & 1,40 & 1.10 & 1,38 & 1,40 \\
\hline $24^{\circ} \mathrm{C}$ & $2,00^{c}$ & $1,80^{c}$ & $2,05^{b}$ & $1,93^{c}$ \\
\hline $30^{\circ} \mathrm{C}$ & $3,05^{a}$ & $2,28^{a}$ & $3,35^{a}$ & $2,70^{a}$ \\
\hline $\begin{array}{c}\text { Note: Letters are the statistical interpretation with Fisher test in which a- very significant, b- distinct significant, } \\
\text { c- significant, d- nonsignificant }\end{array}$
\end{tabular}

four replications per treatment. The results were statistically processed and interpreted with Fisher test.

\section{Results and discussion}

The mycelial growth rates of both species increased progressively along with the rise of incubation temperature. All the experimental strains reached their optimum growth at $24-30^{\circ} \mathrm{C}$. $P$. eryngii strains showed better growth rates compared to those of L. edodes. The fastest strains were Pery-G $\left(4,83 \mathrm{~mm}\right.$ day $\left.^{-1} / 30^{\circ} \mathrm{C}\right)$, Pery-K $(4,14$ $\mathrm{mm}$ day $\left.^{-1} / 30^{\circ} \mathrm{C}\right)$ for P. eryngii and Led-S $(3,35 \mathrm{~mm}$ day $\left.^{-1} / 30^{\circ} \mathrm{C}\right)$, LeM-51 $\left(3,05 \mathrm{~mm}\right.$ day $\left.^{-1} / 30^{\circ} \mathrm{C}\right)$ for L. edodes, respectively. Statistical interpretation (Fisher test) shows that our experimental strains of both species obtained very significant positive results at $30^{\circ} \mathrm{C}$. One strain, Led-S, gave a significant distinct positive result $(2,05 \mathrm{~mm}$ day $^{-1}$ ) at $24^{\circ} \mathrm{C}$, while the other ones revealed only significant results (tab.1. and tab.2.).

\section{Conclusion}

Growth speed of L. edodes and P. eryngii strains cultivated in vitro is determined by genotype and is strongly influenced by temperature. The growth rate increased progressively along with the rise of incubation temperature from $18^{\circ} \mathrm{C}$ to $30^{\circ} \mathrm{C}$. All the experimental strains reached their optimum growth at $24-30^{\circ} \mathrm{C}$. Statistical interpretation shows that our experimental strains of both species obtained very significant positive results at $30^{\circ} \mathrm{C}$. P. eryngii strains showed better growth rates compared to those of $L$. edodes.

Acknowledgments. This work was made with the support of the Ministry of Agriculture and Rural Development - ROMANIA, through the Rural Development Programme- ADER 2015-2018.

\section{REFERENCES:}

1. Chang ST, Miles PG (2008). Mushrooms - Cultivation, Nutritional Value, Medicinal Effect and Environmental Impact, CRC, Press, Boca Raton, Fla, USA, $2^{\text {nd }}$ edition.

2. Chen H, Ju Y, Li J, Yu M (2013). Antioxidant activities of polysaccharides from Lentinus edodes and their significance for Pleurotus eryngii using locally available casing materials. Food Chemistry 138(2-3): 1557-1563.

3. Philippoussis AN (2009). Production of mushrooms using agro-industrial residues as substrates. Cap. 9 Utilisation of Agro-Residues, 163-196. In: Singh, N.P. \& Pandey, A. (eds.) "Biotechnology for Agro-Industrial Residues Processing", Springer. 